\title{
Antioxidant, Larvicidal, and Cytotoxic Studies on Asplenium aethiopicum (Burm. f.) Becherer
}

\author{
Johnson Marimuthu alias Antonysamy, Gowtham Janarthanan, Sivaraman Arumugam, \\ Janakiraman Narayanan, and Narayani Mani
}

Centre for Plant Biotechnology, Department of Botany, St. Xavier's College (Autonomous), Palayamkottai, Tamil Nadu 627 002, India

Correspondence should be addressed to Johnson Marimuthu alias Antonysamy; ptcjohnson@gmail.com

Received 1 March 2014; Revised 5 June 2014; Accepted 17 June 2014; Published 26 August 2014

Academic Editor: Marie Aleth Lacaille-Dubois

Copyright ( 2014 Johnson Marimuthu alias Antonysamy et al. This is an open access article distributed under the Creative Commons Attribution License, which permits unrestricted use, distribution, and reproduction in any medium, provided the original work is properly cited.

\begin{abstract}
The present study was intended to determine the antioxidant, larvicidal, and cytotoxic potential of various extracts of Asplenium aethiopicum (Burm. f.) Becherer. Antioxidant potential of the extracts was determined by the DPPH radical scavenging, phosphomolybdenum, and scavenging of $\mathrm{H}_{2} \mathrm{O}_{2}$. Larvicidal activity of Asplenium aethiopicum was performed against the fourth instar larvae Culex quinquefasciatus. Cytotoxic activity was analysed in terms of brine shrimp lethality bioassay. The best free radical scavenging activity was exerted by methanolic extract of Asplenium aethiopicum $\left(\mathrm{IC}_{50} 91.4 \mu \mathrm{g} / \mathrm{mL}\right.$ ) followed by acetone extract $\left(\mathrm{IC}_{50} 99.8 \mu \mathrm{g} / \mathrm{mL}\right.$ ). Highest larval mortality was observed in the crude acetone extracts of Asplenium aethiopicum against Culex quinquefasciatus $\left(\mathrm{LC}_{50}=166.6 \mathrm{ppm}\right)$ followed by methanolic extracts. Acetone extract of Asplenium aethiopicum was found to be most effective at which $50 \%$ and $90 \%$ mortality of brine shrimp nauplii that occurred were found to be 192.8 and 434.3 ppm, respectively. The results of the present study revealed the antioxidant, larvicidal, and cytotoxic potential of Asplenium aethiopicum.
\end{abstract}

\section{Introduction}

Free radicals which have one or more unpaired electrons (superoxide, hydroxyl, and peroxyl) are produced in normal or pathological cell metabolism and the compounds that can scavenge free radicals have great potential in ameliorating the diseases and pathological cells [1]. Antioxidants play an important role to protect the human body against damage by reactive oxygen species. Plants containing bioactive compounds have been reported to possess strong antioxidant properties [2]. Screening of various bioactive compounds from plants has led to the discovery of new medicinal drugs which have efficient protection and treatment roles against various diseases [3-5].

Mosquito-borne diseases are major threat to over 2 billion people in the tropics. Several mosquito species belonging to genera Culex, Anopheles, and Aedes are vectors for the pathogens of various diseases like malaria, filariasis, Japanese encephalitis, dengue, yellow fever, and chikungunya [6]. The major problems associated with the use of chemicals for the control of pests including mosquitoes include the development of resistance to the chemicals, issues around the residues in animals and the environment, and their undesirable side effects [7]. Extracts from plants may be alternative sources of mosquito control agents, since they constitute a rich source of bioactive compounds that are biodegradable into nontoxic products and potentially suitable for use to control mosquitoes.

Artemia salina L. (Artemiidae), the brine shrimp, is an invertebrate of the fauna of saline aquatic and marine ecosystems. It can be used in laboratory bioassay in order to determine toxicity through the estimation of medium lethal concentration ( $\mathrm{LC}_{50}$ values) which has been reported for series of toxins and plant extracts. Several naturally extracted products which had $\mathrm{LC}_{50}<1000 \mu \mathrm{g} / \mathrm{mL}$ using brine shrimp lethality bioassay (BSLB) were known to contain physiologically active principles [8]. BSLB and other in vivo lethality tests have been successively employed for bioassay guide fractionation of active cytotoxic and antitumor agents $[9,10]$. 
Plant extracts especially phytochemicals (plant derived chemicals) in general have been recognized as an important natural resource and can play an important role against various infectious diseases at the individual as well as at the community level $[11,12]$. Pteridophytes are an important component of the flora of our major region of species diversity, next to angiosperms in number. Different species of ferns have been subjected to pharmacological studies to know the mechanism of action and to know the application of these drugs for the welfare of human beings without any other side effects. India, being a vast country rich in pteridophytes, will be more practical if detailed studies are undertaken on this group. Hence, the present study was intended to study the antioxidant, larvicidal, and cytotoxic potential of Asplenium aethiopicum (Burm. f.) Becherer.

\section{Materials and Methods}

2.1. Collection of Plant Material. Healthy, disease-free ferns of Asplenium aethiopicum (Burm. f.) Becherer were collected near Venkatraman Bridge, Ooty-Gudalur road, Nilgiris, Tamil Nadu, India. The collected samples were brought to the laboratory in plastic bags. They were washed with tap water followed by distilled water to remove the unwanted debris. The plant was blotted on the blotting paper and spread out at room temperature in shade for 20 days. The shade dried samples were ground to fine powder using tissue blender. The powdered samples were then stored in refrigerator at $4^{\circ} \mathrm{C}$ for further analysis.

2.2. Preparation of Extracts. The dried and powered plant materials $(30 \mathrm{~g})$ were successively extracted with $180 \mathrm{~mL}$ of petroleum ether, chloroform, acetone, and methanol by using Soxhlet extractor for $8 \mathrm{~h}$ at a temperature not exceeding the boiling point of the solvent. After evaporation of the solvent under reduced pressure, the weight of each extract was $25.5 \mathrm{~g} / 30 \mathrm{~g}(85 \%)$ for the methanolic extract, $18 \mathrm{~g} / 30 \mathrm{~g}(60 \%)$ for acetone, $17.4 \mathrm{~g} / 30 \mathrm{~g}$ (58\%) for chloroform, and $6.3 \mathrm{~g} / 30 \mathrm{~g}$ (21\%) for the petroleum extract.

2.3. Preliminary Phytochemical Analysis. The different extracts were tested for steroids, terpenoids, alkaloids, phenolic compounds, saponins, tannins, flavonoids, cardiac glycosides, sterols, and amino acids according to the method described by Harborne [13].

2.4. Determination of Total Phenolics and Flavonoids. The total phenolic content was determined according to the method described by Siddhuraju and Becker [14]. The flavonoid contents of all the extracts were quantified as it acts as a major antioxidant in plants, reducing oxidative stress, estimated as described by Zhishen et al. [15].

\subsection{Antioxidant Activity}

2.5.1. DPPH Radical Scavenging Activity. The antioxidant activity of different extracts was determined in terms of hydrogen donating of radical scavenging ability using the stable radical DPPH, according to the method of BrandWilliams et al. [16].
2.5.2. Phosphomolybdenum Assay. The total antioxidant activity was evaluated by the green phosphomolybdenum complex formation according to the method described by Prieto et al. [17]. The results are mean values expressed as $g$ of ascorbic acid (AA) equivalents/100 g extract.

2.5.3. Scavenging of Hydrogen Peroxide. The ability of extracts to scavenge hydrogen peroxide was determined according to the method of Ruch et al. [18]. The percentage inhibition activity was calculated using the formula

$$
\begin{aligned}
& \% \text { scavenging activity } \\
& \qquad=\left[\frac{(\text { Control OD }- \text { Sample OD })}{\text { Control OD }}\right] \times 100 .
\end{aligned}
$$

2.6. Larvicidal Activity. Culex quinquefasciatus (IV instar) larvae were collected from and around Tirunelveli district (sewage) with the help of "O" type brush. These larvae were brought to the laboratory and transferred to $18 \times 13 \times 4 \mathrm{~cm}$ size enamel trays containing $500 \mathrm{~mL}$ of water maintained in the laboratory. C. quinquefasciatus was maintained at $27 \pm 2{ }^{\circ} \mathrm{C}$, 75-85\% RH and 14L: 10D photoperiod cycles. Fourth instar larvae of C. quinquefasciatus were transferred in $250 \mathrm{~mL}$ glass beaker containing desired plant extracts (petroleum ether, chloroform, acetone, and methanol) concentration such as $50,100,150,200$, and $250 \mathrm{ppm}$. The plant extracts were dissolved with acetone for the larvicidal activity. Each and every experiment was performed with five replicates and repeated thrice. $1 \%$ of acetone was used as negative control. The control mortality was corrected by Abbott's formula and $\mathrm{LC}_{50}$ and $\mathrm{LC}_{90}$ regression equation and $95 \%$ confidence limits of lower (LCL) and upper confidence limits (UCL) were calculated by using probit analysis. The standard larvicide Temephos (Abate) was used as positive control.

2.7. Cytotoxic Activity. Artificial sea water ( $38 \mathrm{~g} \mathrm{NaCl} / 1000$ $\mathrm{mL}$ tap water) was taken in small tank and shrimp eggs were added to one side of the divided tank and the side was covered. The shrimps were allowed for $48 \mathrm{hrs}$ to hatch and mature as nauplii. The hatched shrimps were taken for bioassay. Dried methanolic extract of A. aethiopicum was taken in different concentrations $(2.5,5,7.5,10$, and $12.5 \mathrm{mg} / 10 \mathrm{~mL}$ ) to the sample tubes. The methanolic extracts were dissolved with DMSO for the cytotoxic activity. With the help of a Pasteur pipette 10 living shrimps were dropped into each test tube. Control group was added in cytotoxic activity to validate the test method and result obtained due to the cytotoxic activity of the test agent. After 24 hours, the tubes were inspected using a magnifying glass and the number of survived nauplii in each vial was counted and observations were recorded for each vial. Each and every experiment was performed with five replicates and repeated thrice. Using the recorded observations $\mathrm{LC}_{50}, 95 \%$ confidence limit, $\mathrm{LC}_{90}$, and chi square values were calculated. The standard plumbagin was used as positive control. 
TABle 1: Preliminary phytochemical analysis on A. aethiopicum.

\begin{tabular}{|c|c|c|c|c|c|}
\hline Compounds & Pet. ether & Chloroform & Acetone & Methanol & Aqueous \\
\hline Steroids & - & + & + & + & - \\
\hline Alkaloids & - & - & - & + & - \\
\hline Phenolic groups & + & + & + & + & + \\
\hline Cardiac glycosides & - & + & + & + & + \\
\hline Flavonoids & + & + & + & + & + \\
\hline Saponins & - & - & - & - & + \\
\hline Tannins & - & - & - & - & + \\
\hline Amino acids & - & - & - & - & - \\
\hline Terpenoids & - & - & - & - & - \\
\hline Sterols & - & + & + & - & - \\
\hline
\end{tabular}

TABLE 2: Total phenolics and flavonoids contents of A. aethiopicum.

\begin{tabular}{lcc}
\hline Extracts & $\begin{array}{c}\text { Phenolics } \\
(\mathrm{mg} \mathrm{GAE} / \mathrm{g} \pm \mathrm{SD})\end{array}$ & $\begin{array}{c}\text { Flavonoids } \\
(\mathrm{mg} \mathrm{GAE} / \mathrm{g} \pm \mathrm{SD})\end{array}$ \\
\hline Methanol & $371.4 \pm 2.3$ & $261.1 \pm 15.2$ \\
Chloroform & $44.6 \pm 3.2$ & $233.3 \pm 15.2$ \\
Pet. ether & $89.4 \pm 7.1$ & $156.6 \pm 17.6$ \\
Acetone & $453.4 \pm 25.4$ & $358.8 \pm 13.8$ \\
\hline
\end{tabular}

\section{Results and Discussion}

3.1. Phytochemical Analysis. The results of preliminary phytochemical analysis of $A$. aethiopicum were demonstrated in Table 1. Methanol, chloroform, acetone, and aqueous extracts of $A$. aethiopicum showed the maximum presence of five metabolites (Table 1).

3.2. Determination of Total Phenolics and Flavonoids. The total phenolics content of $A$. aethiopicum petroleum ether, acetone, chloroform, and methanolic extracts was determined and presented in Table 2. Maximum amount of extractable total phenolics (453.4 mg GAE/g) was recorded in acetone extracts of $A$. aethiopicum followed by methanolic extracts. Chloroform extracts of $A$. aethiopicum displayed the lowest level of total phenolics (44.6 mg GAE/g) presence. The total flavonoid contents of petroleum ether, acetone, chloroform, and methanolic extracts of $A$. aethiopicum varied considerably from 156.6 to $358.8 \mathrm{mg} \mathrm{GAE} / \mathrm{g}$ (Table 2). Highest amount of flavonoids ( $358.8 \mathrm{mg}$ GAE/g) was present in acetone extracts followed by methanolic and chloroform extracts of A. aethiopicum, respectively. Quantitative estimation of phenolics and flavonoids in various extracts of $A$. aethiopicum determined the presence of extractable compounds with varied percentage.

Phenols and phenolic compounds are greatly used in skin infections, wound healing, inflammation, antioxidant, immune enhancers, anticlotting, and hormone modulators [19]. Flavonoids have a membrane permeability effect and are considered as potential antioxidants and have protective action against allergies, inflammation, free radical, platelet aggregation, microbes, ulcers, hepatotoxins, viruses, and tumor $[20,21]$. The present study results of A. aethiopicum showed the presence of phenolic compounds and flavonoids which are useful as natural antioxidants.

3.3. Antioxidant Activity. The free radical scavenging activity of $A$. aethiopicum petroleum ether, acetone, chloroform, and methanolic extracts was depicted in Table 3. The best free radical scavenging activity was exerted by methanolic extract of A. aethiopicum ( $\mathrm{IC}_{50} 91.4 \mu \mathrm{g} / \mathrm{mL}$ ) followed by acetone extract $\left(\mathrm{IC}_{50} 99.8 \mu \mathrm{g} / \mathrm{mL}\right)$. Chloroform extracts of $A$. aethiopicum showed comparable levels of free radical scavenging activity $\left(\mathrm{IC}_{50} 171.4 \mu \mathrm{g} / \mathrm{mL}\right)$. The free radical scavenging activity was found to be the least in petroleum ether extracts of $A$. aethiopicum.

The results of phosphomolybdenum assay of petroleum ether, acetone, chloroform, and methanolic extracts of $A$. aethiopicum were illustrated in Table 3. Among the various extracts tested, methanolic extracts of A. aethiopicum had the strongest phosphomolybdenum reduction $(188.9 \mathrm{~g}$ $\mathrm{AA} / 100 \mathrm{~g})$. The remaining three extracts of $A$. aethiopicum showed lower level of phosphomolybdenum reduction. The petroleum ether, acetone, chloroform, and methanolic extracts of $A$. aethiopicum showed an efficient $\mathrm{H}_{2} \mathrm{O}_{2}$ scavenging activity in concentration-dependent manner (Table 3 ). Methanolic extracts of $A$. aethiopicum showed maximum inhibition (93.8\%) followed by acetone and chloroform extracts (83.5 and 73.9\%), respectively. Hydrogen/electron transfer from antioxidants to DPPH radical and Mo (VI) complex occur in the DPPH radical and phosphomolybdenum assays, respectively [22]. This reduction ability was relatively shown by the active extracts of $A$. aethiopicum. The results of $\mathrm{H}_{2} \mathrm{O}_{2}$ scavenging activity seem to be an effective scavenger of nitric oxide $\mathrm{H}_{2} \mathrm{O}_{2} \cdot \mathrm{H}_{2} \mathrm{O}_{2}$ can be converted to more reactive species (e.g., the hydroxyl radical), which has been thought to have one of the unfavourable effects caused by it. Hence, the results indicated that $A$. aethiopicum can act as a good scavenger of such harmful radicals.

3.4. Larvicidal Activity. All the four extracts of $A$. aethiopicum showed moderate larvicidal effect after 24 hrs (Table 4). However the highest larval mortality in terms of lethal concentrations for 50\% mortality was observed in the crude acetone extracts of $A$. aethiopicum against C. quinquefasciatus $\left(\mathrm{LC}_{50}=166.6 \mathrm{ppm}\right)$ followed by 
TABLE 3: DPPH radical scavenging activity, phosphomolybdenum assay, and hydrogen peroxide scavenging activity of various extracts of $A$. aethiopicum.

\begin{tabular}{lccc}
\hline Extracts & $\begin{array}{c}\text { DPPH IC } \\
(\mu \mathrm{g} / \mathrm{mL})\end{array}$ & $\begin{array}{c}\text { Phosphomolybdenum } \\
\text { assay (g AA/100 g extract) }\end{array}$ & $\begin{array}{c}\text { Hydrogen peroxide } \\
\text { scavenging activity }\end{array}$ \\
\hline Methanol & 91.4 & $188.9 \pm 4.8$ & $93.8 \pm 0.5$ \\
Chloroform & 171.1 & $20.2 \pm 1.2$ & $73.9 \pm 1.9$ \\
Pet. ether & 514.4 & $22.9 \pm 0.2$ & $67.4 \pm 0.7$ \\
Acetone & 99.8 & $26.2 \pm 0.4$ & $83.5 \pm 2.8$ \\
\hline
\end{tabular}

TABLE 4: Larvicidal activity of A. aethiopicum against C. quinquefasciatus.

\begin{tabular}{lccccc}
\hline Extracts & $\begin{array}{c}\mathrm{LC}_{50} \\
(\mathrm{ppm})\end{array}$ & LCL & UCL & $\begin{array}{c}\mathrm{LC}_{90} \\
(\mathrm{ppm})\end{array}$ & $\chi^{2}(\mathrm{df})$ \\
\hline Pet. ether & 268.1 & 242.2 & 292.3 & 524.2 & 2.712 \\
Chloroform & 288.9 & 261.7 & 315.6 & 357.8 & 0.412 \\
Acetone & 166.6 & 62.1 & 224.6 & 290.4 & 9.216 \\
Methanol & 181.2 & 123.8 & 222.9 & 518.2 & 0.846 \\
\hline
\end{tabular}

$\mathrm{LC}_{50}=$ lethal concentration for $50 \%$ larval mortality; $\mathrm{LC}_{90}=$ lethal concentration for $90 \%$ larval mortality; $\mathrm{LCL}=$ lower confidence limit; $\mathrm{UCL}=$ upper confidence limit.

methanolic extracts $\left(\mathrm{LC}_{50}=181.2 \mathrm{ppm}\right)$. Chloroform extract of $A$. aethiopicum appeared to have lowest effect against $C$. quinquefasciatus $\left(\mathrm{LC}_{50}=288.9 \mathrm{ppm}\right.$ ) when compared to other extracts. The positive control Temephos showed $100 \%$ of mortality at $0.025 \mathrm{ppm}$.

Many approaches have been developed to control mosquito menace. One such approach to prevent mosquitoborne disease is by killing mosquito at larval stage. The current mosquito control approach is based on synthetic insecticides. Even though they are effective, they created many problems like insecticide resistance [23], pollution, and toxic side effect on human beings [24]. Therefore, it is necessary to look for and find the better larvicide which could provide a safer and long-lasting control against all mosquito species. Plant extracts, especially botanical larvicides, provide an alternative to synthetic insecticide because they are generally considered safe, are biodegradable, and can often be obtained from local sources. In addition, the use of medicinal plants for mosquito control is likely to generate local employment, reduce dependence on expensive imported products, and stimulate efforts to enhance public health. In the present study, larvicidal effects of petroleum ether, chloroform, acetone, and methanolic extracts of $A$. aethiopicum against the fourth instar larvae C. quinquefasciatus were tested and the highest larval mortality in terms of lethal concentrations for $50 \%$ mortality was observed in the crude acetone extracts which could be helpful to be applied in integrated control strategies to gain maximum impact on vector control.

3.5. Cytotoxic Activity. The petroleum ether, acetone, chloroform, and methanolic extracts of $A$. aethiopicum showed different mortality rate of brine shrimp which increased proportionally with the increasing concentration of the extract.
TABLe 5: Cytotoxicity of A. aethiopicum against A. salina.

\begin{tabular}{lccccc}
\hline Extracts & $\mathrm{LC}_{50}(\mathrm{ppm})$ & $\mathrm{LCL}$ & $\mathrm{UCL}$ & $\mathrm{LC}_{90}(\mathrm{ppm})$ & $\chi^{2}(\mathrm{df})$ \\
\hline Pet. ether & 302.2 & 269.8 & 335.8 & 655.1 & 3.512 \\
Chloroform & 353.2 & 318.6 & 394.6 & 745.1 & 1.791 \\
Acetone & 192.8 & 162.9 & 217.8 & 434.3 & 1.823 \\
Methanol & 342.6 & 307.6 & 383.3 & 737.8 & 1.419 \\
\hline
\end{tabular}

The inhibitory effect of the extract might be due to the toxic compounds present in the crude extracts. The acetone extract of $A$. aethiopicum was found to be most effective at which $50 \%$ mortality $\left(\mathrm{LC}_{50}\right)$ and $90 \%$ mortality $\left(\mathrm{LC}_{90}\right)$ of brine shrimp nauplii that occurred were found to be 192.8 and $434.3 \mathrm{ppm}$, respectively (Table 5). Chloroform extract showed less cytotoxicity $\left(\mathrm{LC}_{50}=353.2 \mathrm{ppm}\right)$ than other fractions. The $0.046 \mathrm{ppm}$ of standard plumbagin showed $100 \%$ mortality of brine shrimp nauplii.

Bioactive compounds are almost always toxic in high doses. Thus in vivo lethality in a simple zoologic organism can be used as a convenient monitor for screening and fractionation in the discovery of and monitoring bioactive natural compounds [25]. The brine shrimp lethality test is considered to be very useful in determining various biological activities such as cytotoxic, phototoxic, pesticidal, trypanocidal, and enzyme inhibition and ion regulation activities [26]. Recently, there has been interest in the brine shrimp lethality assay as a means of detecting ion regulation or ion-channel activity such as that involving $\mathrm{Na}^{+}-\mathrm{K}^{+}$-ATPase or calcium channels $[27,28]$. It can also be extrapolated for cell-line toxicity and antitumor activity [29]. This is a rapid method utilizing only 24 hours, inexpensive, and needs no special equipment. It is so simple that no aseptic technique is required. It utilizes a large number of organisms for validation and relatively few samples. It does not require animal serum as needed for other methods of cytotoxicity testing [30]. This bioassay has been employed to determine cytotoxic activity of several extracts. In the present study, the different extracts of $A$. aethiopicum showed a marked dose-dependent cytotoxic activity in terms of brine shrimp lethal effect. The lethality of acetone extract of $A$. aethiopicum was found to be most effective which might be due to the toxic compounds present in the crude extracts.

\section{Conclusion}

In the current study, it can be confirmed that the extracts of $A$. aethiopicum defend against harmful free radicals and can find use as broad-spectrum antioxidative agent after 
extensive investigation. Larvicidal effects of $A$. aethiopicum could be helpful to apply in integrated control strategies to gain maximum impact on vector control. Cytotoxic activity of $A$. aethiopicum in terms of brine shrimp lethal effectwas found to be most effective for isolating biogenic compounds from plant extracts.

\section{Conflict of Interests}

The authors declare that they have no conflict of interests.

\section{References}

[1] I. Gülçin, M. Oktay, Ö. I. Küfrevioğlu, and A. Aslan, "Determination of antioxidant activity of lichen Cetraria islandica (L) Ach," Journal of Ethnopharmacology, vol. 79, no. 3, pp. 325-329, 2002.

[2] D. S. Fabricant and N. R. Farnsworth, "The value of plants used in traditional medicine for drug discovery," Environmental Health Perspectives, vol. 109, no. 1, pp. 69-75, 2001.

[3] R. A. Kumar, K. Sridevi, N. V. Kumar, S. Nanduri, and S. Rajagopal, "Anticancer and immunostimulatory compounds from Andrographis paniculata," Journal of Ethnopharmacology, vol. 92, no. 2-3, pp. 291-295, 2004.

[4] K. Sheeja and G. Kuttan, "Activation of cytotoxic T lymphocyte responses and attenuation of tumor growth in vivo by Andrographis paniculata extract and andrographolide," Immunopharmacology and Immunotoxicology, vol. 29, no. 1, pp. 81-93, 2007.

[5] P. K. Mukherjee, V. Kumar, and P. J. Houghton, "Screening of Indian medicinal plants for acetylcholinesterase inhibitory activity," Phytotherapy Research, vol. 21, no. 12, pp. 1142-1145, 2007.

[6] M. W. Service, "Mosquitoes (culicidae)," in Medical Insects and Arachnids, R. P. Lane and R. W. Crosskey, Eds., pp. 723-725, Chapman \& Hall, London, UK, 1993.

[7] R. J. Peter, P. van den Bossche, B. L. Penzhorn, and B. Sharp, "Tick, fly, and mosquito control-lessons from the past, solutions for the future," Veterinary Parasitology, vol. 132, no. 3-4, pp. 205-215, 2005.

[8] S. Pisutthanan, P. Plianbangchang, N. Pisutthanan, S. Ruanruay, and O. Muanrit, "Brine shrimp lethality activity of Thai medicinal plants in the family Meliaceae," Naresuan University Journal, vol. 12, no. 12, pp. 13-18, 2004.

[9] A. V. Krishnaraju and H. S. Tsay, "Biological screening of medicinal plants collected from easternghats of India using Artemia Salina," International Journal of Applied Science and Engineering, vol. 4, pp. 115-125, 2006.

[10] M. A. Alim, A. A. Khan, B. M. Rahman, and M. A. Islam, "In vitro antimicrobial properties and cytotoxic activities of chromium complexes," Research Journal of Agriculture and Biological Sciences, vol. 3, pp. 599-604, 2007.

[11] A. A. Rahuman and P. Venkatesan, "Larvicidal efficacy of five cucurbitaceous plant leaf extracts against mosquito species," Parasitology Research, vol. 103, no. 1, pp. 133-139, 2008.

[12] M. Govindarajan, A. Jebanesan, T. Pushpanathan, and K. Samidurai, "Studies on effect of Acalypha indica L. (Euphorbiaceae) leaf extracts on the malarial vector, Anopheles stephensi Liston (Diptera:Culicidae)," Parasitology Research, vol. 103, no. 3, pp. 691-695, 2008.
[13] J. B. Harborne, Phytochemical Methods: A Guide to Modern Techniques of Plant Analysis, Chapman Hall, New York, NY, USA, 3rd edition, 1998.

[14] P. Siddhuraju and K. Becker, "Studies on antioxidant activities of mucuna seed (Mucuna pruriens var utilis) extract and various non-protein amino/imino acids through in vitro models," Journal of the Science of Food and Agriculture, vol. 83, no. 14, pp. 1517-1524, 2003.

[15] J. Zhishen, T. Mengcheng, and W. Jianming, “The determination of flavonoid contents in mulberry and their scavenging effects on superoxide radicals," Food Chemistry, vol. 64, no. 4, pp. 555$559,1999$.

[16] W. Brand-Williams, M. E. Cuvelier, and C. Berset, "Use of a free radical method to evaluate antioxidant activity," LWT-Food Science and Technology, vol. 28, no. 1, pp. 25-30, 1995.

[17] P. Prieto, M. Pineda, and M. Aguilar, "Spectrophotometric quantitation of antioxidant capacity through the formation of a phosphomolybdenum complex: specific application to the determination of vitamin E," Analytical Biochemistry, vol. 269, no. 2, pp. 337-341, 1999.

[18] R. J. Ruch, S.-J. Cheng, and J. E. Klaunig, "Prevention of cytotoxicity and inhibition of intercellular communication by antioxidant catechins isolated from Chinese green tea," Carcinogenesis, vol. 10, no. 6, pp. 1003-1008, 1989.

[19] I. Hussain, R. Ullah, M. Khurram et al., "Phytochemical analysis of selected medicinal plants," African Journal of Biotechnology, vol. 10, no. 38, pp. 7487-7492, 2011.

[20] O. A. Aiyegoro and A. I. Okoh, "Preliminary phytochemical screening and In vitro antioxidant activities of the aqueous extract of Helichrysum longifolium DC," BMC Complementary and Alternative Medicine, vol. 10, article 21, 2010.

[21] C. O. Eleazu, K. C. Eleazu, E. Awa, and S. C. Chukwuma, "Comparative study of the phytochemical composition of the leaves of five Nigerian medicinal plants," Journal of Biotechnology and Pharmaceutical Research, vol. 3, pp. 42-46, 2012.

[22] A. Y. Loo, K. Jain, and I. Darah, "Antioxidant activity of compounds isolated from the pyroligneous acid, Rhizophora apiculata," Food Chemistry, vol. 107, no. 3, pp. 1151-1160, 2008.

[23] H. Liu, Q. Xu, L. Zhang, and N. Liu, "Chlorpyrifos resistance in mosquito Culex quinquefasciatus," Journal of Medical Entomology, vol. 42, no. 5, pp. 815-820, 2005.

[24] L. Sun, H. Dong, C. Guo et al., "Larvicidal activity of extracts of Ginkgo biloba exocarp for three different strains of Culex pipiens pallens," Journal of Medical Entomology, vol. 43, no. 2, pp. 258261, 2006.

[25] J. L. Mclaughlin, L. L. Rogers, and J. E. Anderson, "The use of biological assays to evaluate botanicals," Drug Information Journal, vol. 32, no. 2, pp. 513-524, 1998.

[26] J. E. Anderson, C. M. Goetz, J. L. McLaughlin, and M. Suffness, "A blind comparison of simple bench-top bioassays and human tumor cell cytotoxicities as antitumor prescreens," Phytochemical Analysis, vol. 2, pp. 107-111, 1991.

[27] J. L. Borowitz and J. L. McLaughlin, "Evidence for calcium channels in brine shrimp: diltiazem protects shrimp against cadmium," Bulletin of Environmental Contamination and Toxicology, vol. 48, no. 3, pp. 435-440, 1992.

[28] S. A. Watts, E. W. Yeh, and R. P. Henry, "Hypoosmotic stimulation of ornithine decarboxylase activity in the brine shrimp 
Artemia franciscana," Journal of Experimental Zoology, vol. 274, no. 1, pp. 15-22, 1996.

[29] T. W. Sam, "Toxicity testing using the brine shrimp: Artemia salina," in Bioactive Natural Products Detection, Isolation, and Structural Determination, pp. 442-456, 1993.

[30] A. M. Hossain, T. Ferdous, S. M, Salehuddin., and A. K. Das, "In vitro cytotoxicity $\left(\mathrm{LC}_{50}\right)$ of extracts obtained from the seeds of Zea mays," Asian Journal of Food \& Agro-Industry, vol. 2, pp. 336-344, 2009. 

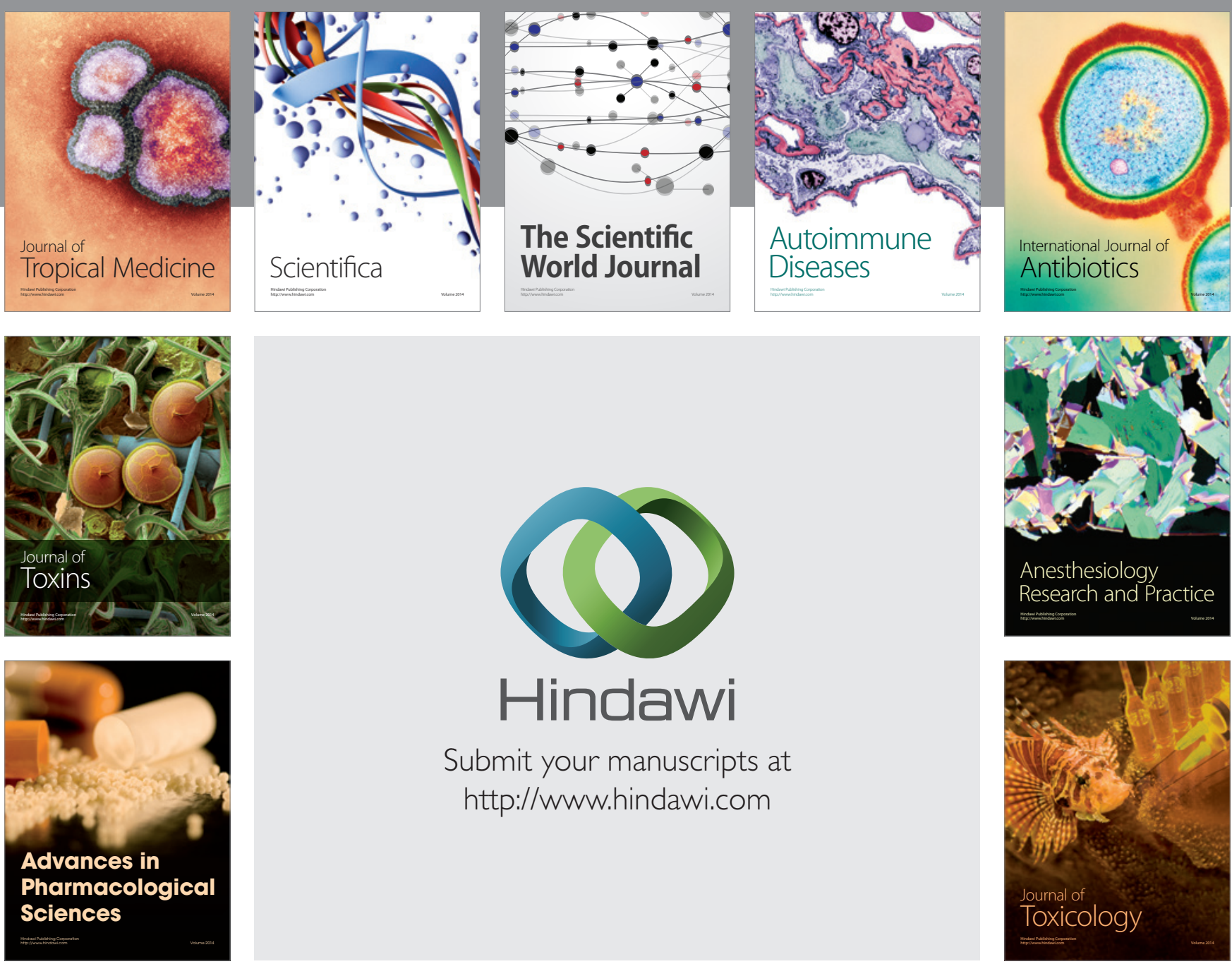

\section{Hindawi}

Submit your manuscripts at

http://www.hindawi.com
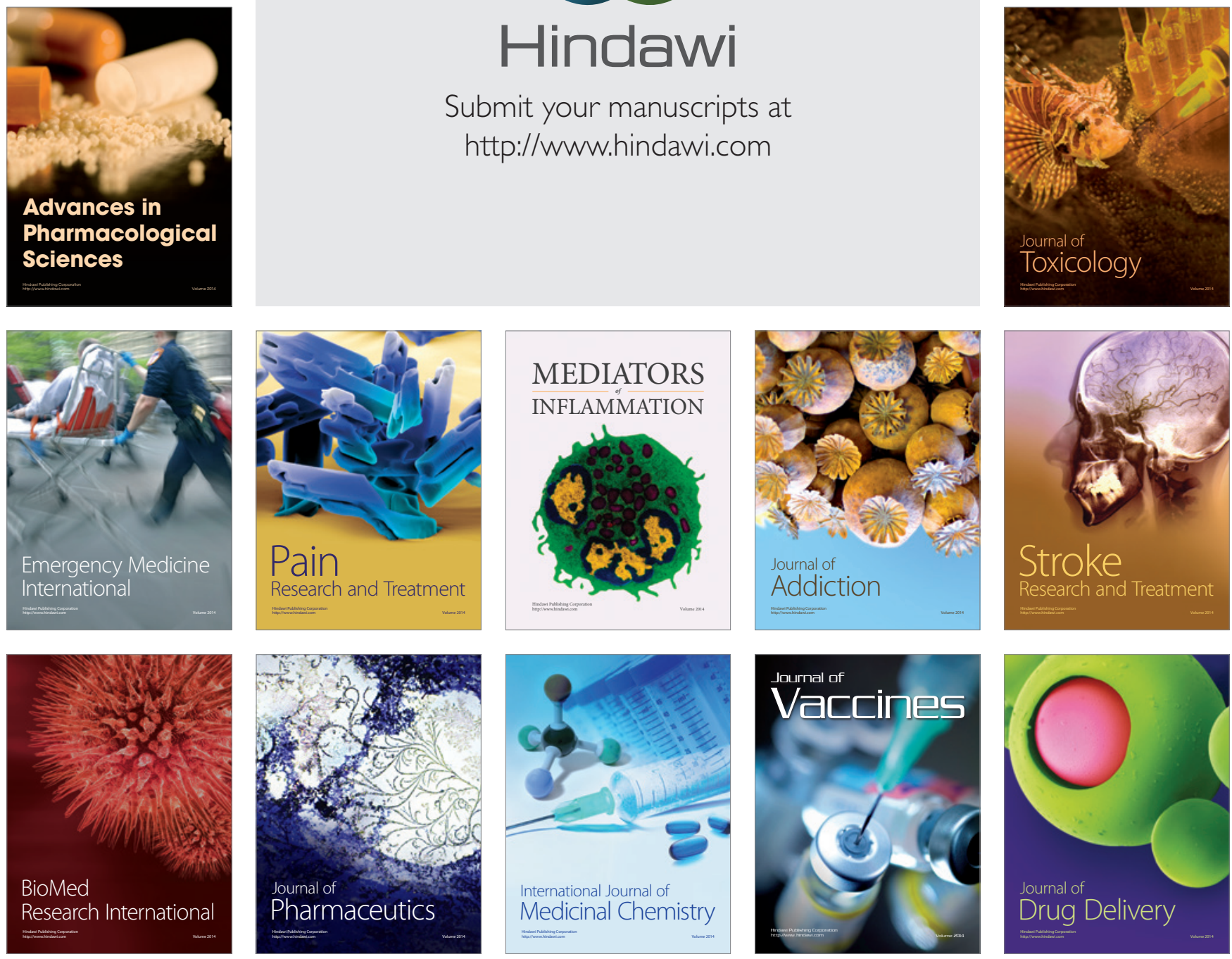